\title{
Drug safety legislation closer to passing
}

$\mathrm{F}$ ourteen years after his teenage daughter died while taking a prescription drug that was later pulled from the market, a federal politician is celebrating the progression of a bill he introduced to bolster oversight of drug safety in Canada.

Bill C-17, which amends the Food and Drugs Act to tighten regulation of prescription and over-the-counter drugs, vaccines, gene therapies and medical devices, has passed second reading in the House of Commons. The bill, which has all-party support, headed to the Standing Committee on Health June 6, where New Democrat Party (NDP) and Liberal members plan to introduce amendments to further strengthen the bill. The revised bill will then return to the House for a third reading and vote.

The draft legislation, the Protecting Canadians Against Unsafe Drugs Act, is also known as Vanessa's Law, after Vanessa Young, who collapsed and died in 2000 while taking Propulsid (cisapride). Janssen-Ortho Inc. voluntarily removed cisapride from the US market in July 2000 and from Canada in August 2000 after multiple reports of serious cardiac arrhythmias and deaths associated with the drug.

Vanessa's father, Conservative MP Terence Young, has spent the years since Vanessa's death campaigning for better postmarket surveillance and prescription drug regulation - a cause that helped propel him into federal politics, he told CMAJ. "I've been doing this work since Vanessa died," said Young, who was previously a provincial politician, said "I didn't ask for this work; it was given to me to do." He initially created the nonprofit organization Drug Safety Canada, but after years of lobbying federal MPs, realized he could do more if he were in Parliament himself.

The bill Young introduced in October 2013 would give the federal minister of health authority to order a drug that presents a serious risk of injury off the market - a power most regulators in other countries already have, but which Canada currently lacks. When serious adverse safety effects are voluntarily reported, Health Canada currently negotiates with the drug's manufacturer to add stronger warnings to its label, or to have it voluntarily withdraw the product from the market.

That lack of regulatory authority was most acutely shown in 1962, when Canada had to pass a special act of Parliament to pull thalidomide from pharmacies. Thalidomide, which was then being prescribed to pregnant women to treat morning sickness, was responsible for thousands of serious birth defects worldwide.

"Here we are, more than 50 years later and we still have this gaping hole in Canada's Food and Drugs Act," NDP MP Libby Davies told the House of Commons. "We are very glad that the bill would allow the minister to recall drugs," said Libby, who is vice-chair of the Standing Committee on Health.

The proposed legislation would also enable Health Canada to order manufacturers to amend labelling, to provide the regulator with information it requires to

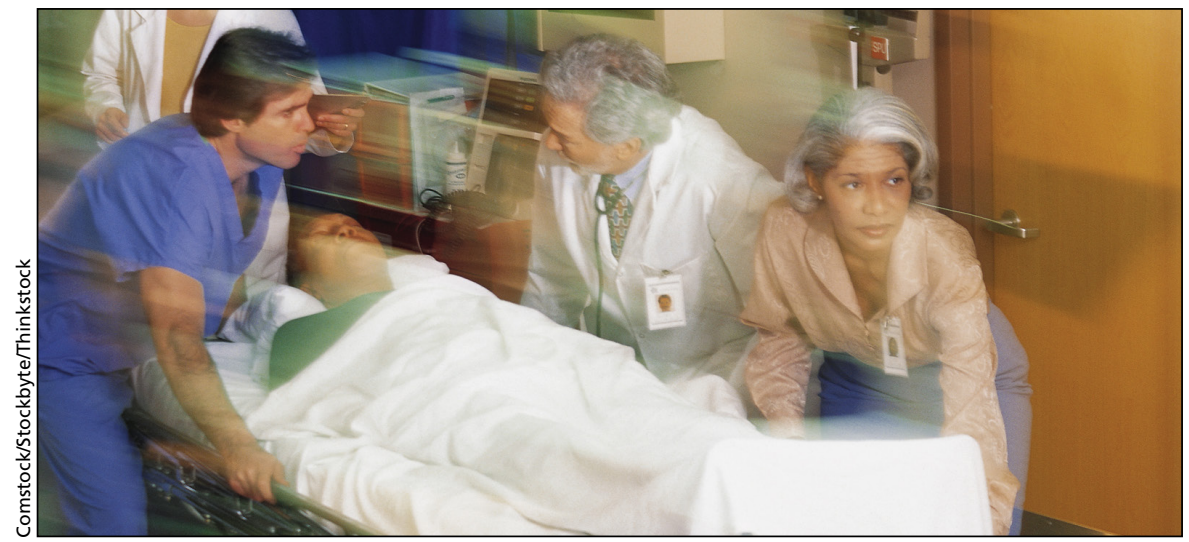

Bill C-17 gives the government authority to order a drug off the market if it poses a significant risk. Most countries already have such regulations. determine safety and to monitor and report on postmarket safety. The bill provides for fines of up to $\$ 5$ million a day or an unlimited amount for companies that market unsafe products.

During discussion in the House the week of June 2, members of all parties praised the bill as an excellent step forward, but the NDP, Liberal and Green parties also want strong amendments that include mandatory registration and outcome reporting of clinical trials - something Young said he would welcome.

He cited a CMAJ article calling for the critical review of the bill and additions in six areas, a critique that Young called "very helpful."

Canada needs to join the European Union and other jurisdictions in mandatory registration and reporting the trial data as well as the results of clinical trials and of observational studies, said Matthew Herder, who coauthored the article that several MPs cited during the debate.

"If they have those three things in there, with penalties for failing to do them, that would be an important move," said Herder, an assistant professor in medicine and law at Dalhousie University in Halifax. He also called for more transparency in Health Canada's decisions to approve or deny a drug's registration.

Adequate financing is also essential to the bill's success. Both Herder and Davies said the federal government needs to hire more drug safety experts at Health Canada to enforce the bill's tougher requirements. "If you continue to underfund the therapeutic drugs branch, it's all going to be for naught," Herder said.

Young hopes the bill will be voted on before Parliament breaks for the summer later in June.

Health Minister Rona Ambrose has said she will consider any amendments that improve the legislation. Young also vowed to continue to advocate for the resources necessary to make sure this proposed legislation is effective.

"There is no going back. There will be money to enforce these laws; there is no doubt in mind," said Young. Laura Eggertson, Ottawa, Ont. 